\title{
PERMASALAHAN DAN TANTANGAN GURU PKn MENGHADAPI PERUBAHAN KURIKULUM (2013)
}

\author{
Yosaphat Haris Nusarastriya \\ Program Studi S1 PPKn \\ FKIP Universitas Kristen Satya Wacana
}

\begin{abstract}
ABSTRAK
Perubahan kurikulum selalu untuk menjawab tantangan yang sedang dirisaukan masyarakat, salah satunya ialah karena siswa lebih cenderung memiliki (mendapatkan) kompetensi kognitif. Apa yang harus dijawab dengan kurikulum mendatang? Untuk menjawab pertanyaan itu harus mengerti benar tentang kelemahan dalam pendidikan pada umumnya di Indonesia. Banyak ahli menilai bahwa pendidikan di Indonesia lebih mengisi pikiran dari pada mengajarkan cara berpikir. Hasil berpikir dan bernalar siswa-siswa Indonesia masih rendah dan oleh karena itu tantangan terbesar pendidikan di Indonesia adalah bagaimana menerjemahkan konsep successful intelligence (SI) ke dalam operasional sistim pendidikan. Pendidikan di Indonesia nampaknya belum berhasil membentuk SI, khususnya dalam kemampuan berpikir tingkat tinggi. Dalam hal inilah tantangan guru PKn menghadapi kurikulum 2013 yang arahnya tidak hanya memberi pengetahuan tetapi juga mengajar cara berpikir. Pendidikan Pancasila dan Kewarganegaraan memiliki kepentingan untuk menterjemahkan berpikir tingkat tinggi dalam proses pem-belajarannya karena salah satu tujuan Pendidikan Pancasila dan Kewarganegaraan adalah membentuk kepribadian di mana berpikir kritis merupakan unsur penting dalam kepribadian itu.
\end{abstract}

Kata Kunci: Perubahan Kurikulum, Tantangan Guru dan Pendidikan Berpikir Kewarganegaraan.

\section{PENDAHULUAN}

Perubahan kurikulum selalu untuk menjawab tantangan yang sedang dirisaukan masyarakat, salah satunya ialah karena siswa lebih cenderung memiliki (mendapatkan) kompetensi kognitif dalam proses pembelajarannya.

Apa yang harus dijawab dengan kurikulum 2013? Untuk menjawab pertanyaan itu harus mengerti benar tentang kelemahan dalam pendidikan yang sedang berlangsung. Di Indonesia kelemahan itu berkaitan dengan masih lemahnya pada aspek bernalar. Sedangkan tantangan terbesar pendidikan di Indonesia berkaitan dengan bagaimana mengupayakan proses belajar mengajar agar dapat mengatasi kondisi rendahnya kemampuan berpikir. Dalam hal inilah tantangan guru pada umumnya dan guru PKn pada khususnya

Tulisan ini pernah disajikan dalam Forum Guru-Guru PKn Salatiga dan Sekitarnya di UKSW April 2013 dan telah disempurnakan. menghadapi kurikulum 2013 yang penerapannya sudah dilakukan di beberapa sekolah.

\section{Kurikulum 2013}

Sebelumnya perlu diajukan pertanyaan sebagai berikut: "Kemana arahnya dengan perubahan kurikulum 2013 ini?". Saya setuju dan menggaris bawahi sebagaimana yang dikemukakan oleh Suyadi (2013), bahwa perubahan kurikulum sudah jelas arahnya, yaitu perubahan kurikulum dimaksudkan dapat meningkatkan dan menyeimbangkan antara kompetensi sikap (attitude), keterampilan (skills) dan pengetahuan (knowledge).

Apa yang harus dijawab dengan kurikulum mendatang? Rupanya perubahan kurikulum selalu untuk menjawab tantangan yang sedang dirisaukan masyarakat, salah satunya ialah karena anak-anak (peserta didik) lebih cenderung memiliki (mendapatkan) kompetensi kognitif. Kerisauan masyarakat sebagaimana yang dikemukakan 
oleh Suyadi di atas ternyata juga dirasakan oleh Abduhzen (2013) yang mengemukakan bahwa kemampuan berpikir dan bernalar siswa-siswa Indonesia masih rendah. Pernyataan itu bersumber dari hasil penelitian Internasional yang memposisikan Indonesia berada pada urutan terendah. Menurutnya itu pulalah yang menjadi dasar bagi pemerintah untuk mengubah kurikulum pendidikan. Abduhzen menambahkan bahwa selama ini model pendidikan di Indonesia hanya mengisi pikiran, tetapi tak mengajarkan berpikir. Karena itulah orang Indonesia sangat lemah dalam berpikir dan bernalar.

Senada dengan Abduhzen, Megawangi dalam Forum Mangunwijaya VII (2013) mengemukakan bahwa tantangan terbesar pendidikan kita adalah bagaimana menerjemahkan konsep successful intelligence (SI) ke dalam operasional sistim pendidikan. Menurutnya pendidikan di Indonesia belum berhasil membentuk SI, misalnya dalam kemampuan berpikir tingkat tinggi (higher order thinking skills/HOTS). Hal itu berdasarkan data dari TIMMS 2007 (Trends in International Math and Science Survey), dimana hanya satu persen siswa Indonesia memiliki kemampuan berpikir advanced. Secara rinci perbandingannya dengan negara lain adalah dapat dilihat pada tabel yang menunjukkan diantara negara-negara Asia (Taiwan, Korea Selatan, Singapura, Hongkong, Jepang) Indonesia berada pada posisi terendah sebagai berikut:

\begin{tabular}{llll}
\hline No & \multicolumn{1}{c}{ Negara } & \multicolumn{1}{c}{$\begin{array}{c}\text { Higher Order } \\
\text { Thinking Skills } \\
\text { (Hots) }\end{array}$} & $\begin{array}{c}\text { Lower Order } \\
\text { Thinking Skills } \\
\text { (Lots) }\end{array}$ \\
\hline 1 & Indonesia & $1 \%$ & $78 \%$ \\
2 & Taiwan & Rata-rata di atas 40\% & Dibawah 15\% \\
3 & Korea Selatan & Rata-rata di atas 40\% & Dibawah 15\% \\
4 & Singapura & Rata-rata di atas 40\% & Dibawah 15\% \\
5 & Hongkong & Rata-rata di atas 40\% & Dibawah 15\% \\
6 & Jepang & Rata-rata di atas 40\% & Dibawah 15\% \\
\hline
\end{tabular}

Disarikan dari: Forum MangunwijayaVII, Penerbit Kompas, (2013)
Oleh karena itu kurikulum hendaknya dapat menjawab masalah tersebut dengan tidak hanya memberi kompetensi kognitif saja, melainkan ada sikap dan keterampilan yang didasari tiga pilar utama yakni, kreatif, inovatif dan produktif. Dengan kata lain Kurikulum 2013 adalah hendaknya merupakan kurikulum yang mencerdaskan. Kurikulum yang baru diharapkan akan dapat merubah mindset pendidikan menjadi dua paradigma yakni akademik dan karakter. Maksud dari ungkapan cerdas akademik adalah kreativitas anak dipacu dengan cara anak diajari mengamati, memanfaatkan inderawi untuk melihat fenomena. Dengan mengamati dimaksudkan anak juga didorong untuk bertanya. Dengan bertanya-tanya anak akan sampai pada tingkat bernalar, dan akhirnya sampai bereksperimen.

Menurut Nugroho (2013) ada lima hal yang harus dilakukan guru agar sukses menjadi pelaku implementasi KK 2013. Kelima hal tersebut meliputi: penguasaan pembelajaran dengan pendekatan tematik, penguasaan pedagogi materi subjek, kemampuan mengajarkan keahlian berpikir, kemampuan mengembangkan dan mengimplementasikan authentic assessment dan yang terakhir adalah kemampuan untuk membangun mindset perubahan dalam dirinya.

\section{Ketrampilan Berpikir Tingkat Tinggi}

Kaitannya dengan tulisan ini, apa yang dikemukakan Nugroho (2013) memperlihatkan satu hal yang relevan yaitu tentang ketrampilan berpikir. Ketrampilan berpikir dinyatakan sebagai salah satu nilai lebih KK 2013 dimana orientasi ideologisnya secara sadar mengarahkan siswa untuk menguasai kemampuan berpikir tingkat tinggi (higher order thinking) sebagai prakondisi untuk bersaing di abad 21 ini. Nugroho juga mencatat bahwa sampai hari ini praktis pendidikan negeri ini dominan mengajarkan kemampuan berpikir tingkat rendah (lower order thinking) sebagaimana yang berlangsung di sekolah setiap hari anak-anak diajarkan untuk mahir dalam 
menghafal dan menirukan. Menurutnya sejak duduk di bangku LPTK, mahasiswa calon guru memang kurang dibekali ketrampilan mengajarkan kemampuan berpikir tingkat tinggi. Bekal yang mahasiswa dapat masih sebatas bagaimana mengajarkan materi pelajaran sehingga akibatnya sampai ketika menjadi guru juga hanya berkutat bagaimana mengajarkan materi subjek bukan mengajarkan keahlian berpikir tingkat tinggi sesuai bidang studi atau matapelajarannya. Wajar saja jika kini mereka gagap dan gugup jika dituntut bisa mengajarkan berpikir tingkat tinggi. (Nugroho:2013)

Selanjutnya Al Muhtar, Abdul Karim (2011) dalam Nusarastriya (2013) mengemukakan bahwa kualitas pendidikan masih lemah dengan ditandai oleh salah satu cirinya yaitu proses pendidikan yang memberikan sebanyak mungkin bahan pelajaran untuk mencapai target kurikulum, sedangkan kapasitas berpikir tidak ditingkatkan kepada tarap yang optimal (higher order thinking skills). Keprihatinan semacam itu juga muncul dari Sanusi (1998:222-227) dalam Nusarastriya (2013) dalam pembahasannya mengenai perspektif pendidikan Ilmu (Pengetahuan) Sosial yang mengemukakan bahwa pengajaran IPS di sekolah cenderung menitikberatkan pada penguasaan hafalan dan pencapaian tujuan kognitif yang "mengulit bawang" dan dominannya latihan berpikir taraf rendah.

Kritikan tajam muncul juga dari Pitalokasari, I. (2012) dalam Nusarastriaya (2013) yang menyoroti proses pembelajaran kaitannya dengan kualitas lulusan Perguruan Tinggi yang mengatakan bahwa "jika dosen masih menggunakan metode mengajar 'konvensional, maka kurikulum sebagus apa pun tidak bisa membentuk lulusan yang berkualitas". Menanggapi pernyataan yang keras tersebut penulis mengerti maksudnya bahwa mengajar perlu variasi dalam prosesnya sehingga jangan hanya didominasi oleh guru/ dosen melainkan ada inovasi sehingga terjadi keseimbangan antara pendekatan teacher centre strategies, material centre strategies dan student centre strategies.

\section{Komponen penting yang harus diperhatikan Guru PKn}

Pendidikan Kewarganegaraan (PKn) sangat besar andilnya untuk membentuk kepribadian yang cerdas sebagai warga negara. Oleh karena itu PKn harus dikemas dengan baik, dengan model pembelajaran yang sesuai dengan tingkat perkembangan berpikir siswa. Walaupun setiap tingkat satuan pendidikan belum tentu sama model pembelajarannya, namun demikian dari beberapa tingkatan/jenjang pendidikan ada tujuan pengiring yang sama yaitu pengembangan berpikir siswa. UNESCO menyatakan bahwa belajar pada abad 21 harus didasarkan kepada empat pilar yaitu:

\section{Learning how to know \\ 2. Learning to do \\ 3. Learning how to live together \\ 4. Learning to be}

Keempat hal tersebut oleh UNESCO disebut sebagai empat pilar belajar dari manusia abad 21 untuk menghadapi arus informasi dan kehidupan yang terus menerus berubah. Arus informasi yang begitu cepat berubah semakin lama semakin banyak tidak mungkin lagi dikuasai oleh manusia karena kemampuan otaknya yang terbatas. Oleh sebab itu proses yang terus menerus terjadi seumur hidup ialah antara lain belajar bagaimana belajar berpikir. Bagaimana belajar berpikir termasuk dalam learning how to know (Nusarastriya:2013).

Selaras dengan empat pilar khususnya pilar mengenai learning how to know dimana di dalamnya termasuk learning how to think, maka pembiasaan berpikir dalam proses pembelajaran PKn merupakan upaya yang sangat sesuai dengan tujuan nasional sebagaimana yang dimuat di dalam Pembukaan UUD 1945 yang berbunyi mencerdaskan kehidupan bangsa. Hal itu berarti dunia pendidikan mempunyai tanggung jawab yang strategis untuk ikut mewujudkannya melalui proses belajar dan mengajar di sekolah dari level yang paling rendah sampai pendidikan tinggi.

\section{Permasalahan}

Dalam kenyataannya PKn sering dipandang dengan sebelah mata dan diremehkan serta 
terkesan kurang menarik bahkan dirasa membosankan karena hanya begitu-begitu saja. Fenomena inilah yang harus disikapi dengan serius oleh komunitas Pendidik PKn. Hal semacam ini harus dijadikan tantangan dengan mengembangkan PKn dari berbagai segi baik itu yang menyangkut proses pembelajarannya, materi, metode pembelajaran, media pembelajarannya dan pengemasannya.

Rasanya dibutuhkan keseriusan menangani PKn ini yang berarti dibutuhkan pengembangan atau aktualisasi supaya benar-benar menarik dan menyenangkan sehingga efektif dalam mencapai tujuannya. Salah satu hal yang menurut penulis harus diperhatikan adalah perlunya memberi spirit berpikir. Walaupun dalam konteks PKn posisinya sebagai tujuan pengiring tetapi kalau itu tidak berhasil mengembangkan cara berpikir (pemikiran) warga negara maka tujuan PKn juga tidak akan mencapai kompetensi yang diharapkan. Pemberian spirit berpikir dalam PKn mensyaratkan adanya model pembelajaran tertentu, karena tidak semua model memberi peluang yang besar bagi tumbuhnya spirit berpikir. Oleh karena itu model pembelajaran yang memberi kesempatan siswa untuk mengembangkan cara berpikir kewarganegaraan dalam PKn harus diupayakan dalam proses pembelajaran di setiap jenjang/satuan tingkat pendidikan dari SD sampai Perguruan Tinggi.

Memberi spirit berpikir dalam PKn akan sangat membantu tercapainya kompetensi yang diharapkan. Alasannya yaitu salah satu tujuannya adalah membentuk kepribadian yang cerdas sebagai warga negara. Oleh sebab itu pembiasaan berpikir dalam proses-proses pembelajarannya sangat diharapkan agar kompetensi bisa dicapai. Arah dari pembelajaran yang memberi spirit berpikir tidak lain adalah tercapainya apa yang disebut dengan kecerdasan majemuk.
Untuk mencapai kompetensi yang diharapkan sebagaimana tuntutan kurikulum 2013, guru PKn harus memperhatikan tiga komponen dasar dalam Civic Education yaitu: Civic knowledge, Civic values, Civic skills. Jika tiga komponen utama ini diberikan secara proporsional melalui proses pembelajaran maka akan memenuhi harapan sebagaimana yang dituntut melalui perubahan kurikulum 2013 yang arahnya dimaksudkan dapat meningkatkan dan menyeimbangkan antara kompetensi sikap (attitude), keterampilan (skills) dan pengetahuan (knowledge). Kompetensi Pendidikan Kewarganegaraan yang meliputi: Civic knowledge, Civic values, Civic skills tidak akan tercapai jika guru hanya menekankan pada kompetensi kognitif saja, karena baru mengenai civic knowledge. Secara skematis tiga komponen utama Civic Education dapat dilihat pada skema 1 .

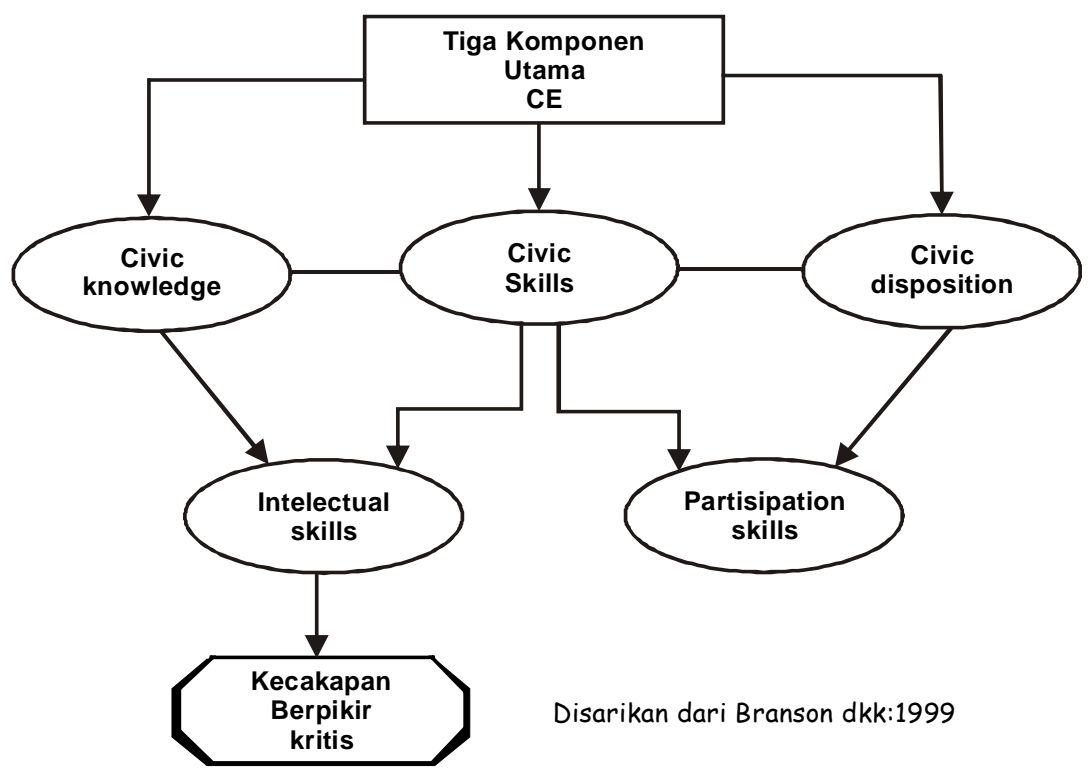

Skema 1 Civic Education 


\section{Tantangan Bagi Guru PKn (PPKn)}

Guru yang professional akan berpikir tentang apa yang akan diajarkan, bagaimana itu di ajarkan, siapa yang menerima pelajaran, apa makna belajar bagi siswa, kemampuan apa yang ada pada siswa dalam mengikuti kegiatan belajar mengajar. Guru biasanya memberi tekanan yang berbeda-beda terhadap komponen-komponen pengajaran. Pemberian tekanan pada aspek tertentu pada strategi belajar-mengajar itu sangat tergantung pada persepsi guru tentang apa belajar dan mengajar itu? Jika menggunakan pendekatan Fromm (1976:22) maka akan dikenal dua modus yaitu modus "memiliki" dan modus "menjadi".

Untuk melaksanakan proses pembelajaran dalam kerangka kurikulum 2013 maka guru PKn hendaknya memilih model atau metode serta strategi pembelajaran yang dapat menyeimbangkan dua modus yaitu tidak hanya berhenti pada "modus memiliki tetapi juga mencakup "modus menjadi", tidak hanya mengisi pikiran tetapi juga mengajar bagaimana berpikir, tidak hanya memberi pengetahuan (aspek kognitif/ knowledge), tetapi juga menyeimbangkan dengan aspek skills dan attitude (sikap/karakter).

Perbedaan tekanan pada dua modus menurut Erich Formm dapat dilihat pada tabel 2.

Untuk itu perlu inovasi dalam proses pembelajaran khususnya di dalam mengisi perubahan kurikulum 2013. Pada kesempatan ini perlu memberi tekanan pada pendidikan berpikir dalam pembelajaran PKn agar tidak sekedar memberi materi tetapi juga skills, yaitu keterampilan berpikir kritis. Berpikir kritis bukan hanya merupakan tuntutan dalam PKn tetapi dalam pembelajaran pada umumnya menghadapi era globalisasi dimana guru tidak lagi menjadi satusatunya sumber informasi bagi siswa karena mereka (siswa) sudah mengenal berbagai sumber informasi seperti internet, Face Book, Twiter, BB, $\mathrm{TV}$, majalah, buku-buku dsb.

Pada skema 2, diberikan contoh "Desain untuk Pengembangan Berpikir Kritis" yang bisa digunakan untuk tidak sekedar mengajar aspek kognitif saja tetapi juga melatih berpikir kritis menghadapi berbagai objek (informasi, fenomena, pernyataan dll) sehingga siswa mengalami proses habituasi dalam PBM. Jika Kurikulum 2013 siswa diajari mengamati, memanfaatkan inderawi untuk melihat fenomena, bertanya agar siswa bisa sampai pada tingkat bernalar, dan akhirnya sampai bereksperimen maka perlu pilihan metode pembelajaran yang memiliki kontribusi pada hal-hal tadi. Dalam Desain ini digunakan Project Citicen (PC) yang intinya ada enam langkah yaitu (1) Mengidentifikasi masalah kebijakan publik yang ada dalam masyarakat, (2) Pemilihan masalah sebagai fokus kajian kelas, (3) Pengumpulan informasi terkait masalah yang menjadi fokus kajian kelas, (4) Pengembangan suatu portofolio kelas, (5) Penyajian portofolio (show case), (6) Kajian pengendapan atas pengalaman belajar yang dilakukan.

Tabel 2 Belajar Menurut Erich Fromm

\begin{tabular}{ll}
\hline Dalam Modus 'Memiliki” & Dalam Modus “menjadi”' \\
\hline Menghafal & Memahami \\
Pasif & Aktif \\
$\begin{array}{l}\text { Berpegang terus pada apa yang mereka } \\
\text { telah pelajari }\end{array}$ & Menanggapi apa yang mereka dengar \\
Memegang/menyimpan pengetahuan & Timbul pertanyaaan-pertanyaan baru \\
Tidak perlu menciptakan sesuatu yang baru & $\begin{array}{l}\text { Produktif, tidak sekedar memperoleh } \\
\text { pengetahuan }\end{array}$ \\
\hline
\end{tabular}

Disarikan dari Fromm, Erich (1976:22-23) 
Pertama, perlu menentukan apa yang dimaksud berpikir kritis dan komponen apa saja yang harus dipenuhi sehingga disebut berpikir kritis? Dengan menggunakan komponen yang telah ditentukan kita dapat menggunakan untuk melihat sejauhmana pemahaman siswa mengenai berpikir kritis tersebut. Hal ini perlu analisis supaya tahu hasil pemahaman yang berkaitan dengan komponen mana yang masih lemah dan yang sudah baik. Kedua, perlu dilakukan analisis materi dilihat dari tingkat berpikir (mana materi yang bersifat deskriptif, mana materi yang memuat analisis-sintesis dan mana materi yang mencerminkan cara berpikir linear dan mana materi yang menuntut berpikir kompleks. Ketiga, maping (pemetaan) mana materi yang berkaitan dengan tuntutan berpikir kritis sesuai dengan tingkatan berpikir siswa dihubungkan dengan kompetensi yang diharapkan. Keempat, pemilihan metode pembelajaran yang memang dapat mendukung terwujudnya skills (dalam hal ini kemampuan / ketrampilan berpikir kritis). Kelima, proses pembelajaran menggunakan metode yang dimaksud. Keenam, maping (membuat pemetaan) soal/tes dengan tuntutan berpikir yang disesuaikan dengan tuntutan kompetensi.

\section{PENUTUP}

Menghadapi tantangan perubahan kurikulum, guru perlu meninjau dan berefleksi

mengenai beberapa hal seperti materi yang diajarkan, cara mengajar, sarana belajar-mengajar, proses pembelajaran. Kurikulum 2013 dibuat bukan tanpa dasar tetapi berangkat dari adanya persoalan dan kebutuhan. Arah perubahan kurikulum dimaksudkan dapat meningkatkan dan menyeimbangkan antara kompetensi sikap (attitude), keterampilan (skills) dan pengetahuan (knowledge). Guru PKn hendaknya memilih model atau metode serta strategi pembelajaran yang dapat menyeimbangkan dua modus yaitu tidak hanya berhenti pada "modus memiliki tetapi juga mencakup "modus menjadi", tidak hanya mengisi pikiran tetapi juga mengajar bagaimana berpikir, tidak hanya akademis tetapi juga karakter dan tidak hanya aspek kognitif tetapi juga afektif dan psikomotorik. Aplikasi dan operasionalisasi berpikir kritis dan berpikir tingkat tinggi dalam mata pelajaran serta dalam operasionalisasi sistem pendidikan.

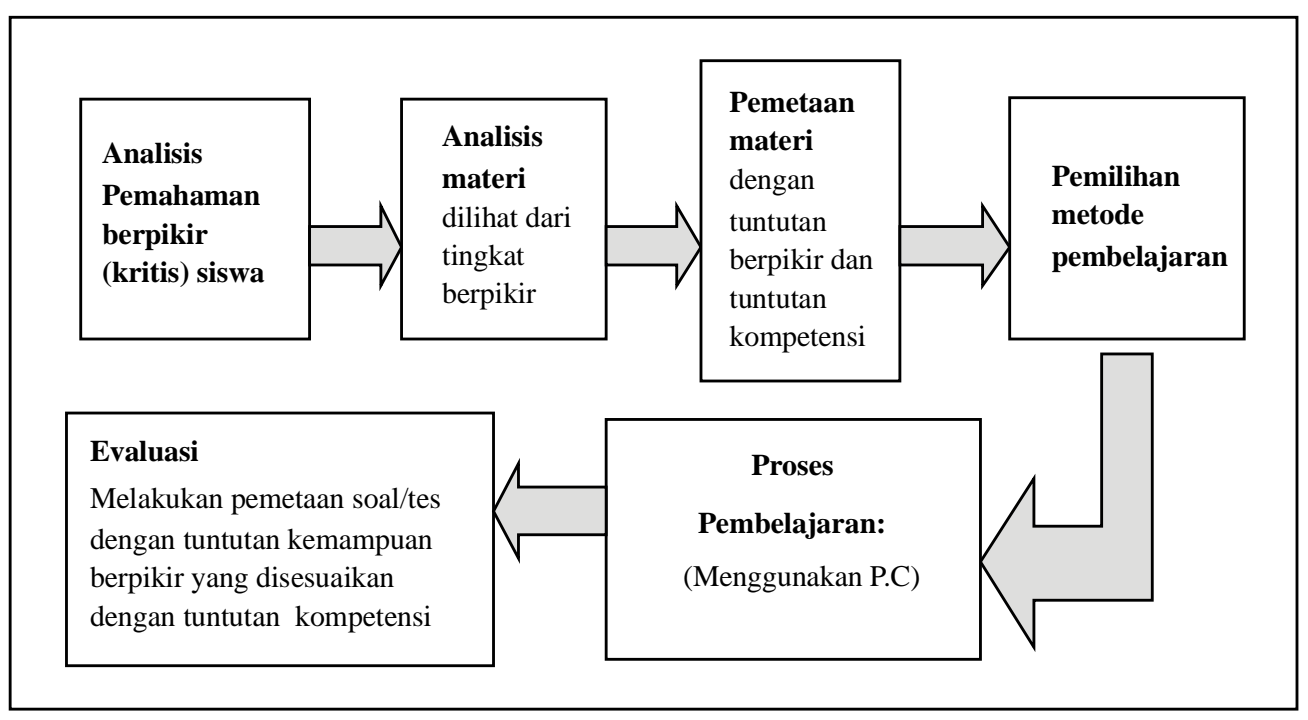

Skema:2. Contoh Desain Pembelajaran Untuk Pengembangan Berpikir 


\section{DAFTAR PUSTAKA}

Abduhzen, Mohammad. 2013. Pendidikan Kita Belum Mengajar Berpikir. Suara Merdeka, 13 Januari 2013.

Branson M.S. dkk. 1999. Belajar Civic Education dari Amerika. LkiS kerja sama.

Fromm, E. 1976. Memiliki dan Menjadi: Tentang Dua Modus Eksistensi (Terj: F. Soesilohardo), Jakarta: LP3ES.

Forum MangunwijayaVII. 2013. Menyambut Kurikulum 2013. Jakarta, Kompas.

Nusarastriya. 2013. Pengembangan Berpikir Kritis Dalam Pembelajaran Pendidikan Kewarganegaraan Menggunakan Project Citizen. Disertasi Doktor Pada Universitas Pendidikan Indonesia Bandung, tidak diterbitkan.
Nugroho. 2013. Kurikulum 2013 Butuh Guru Hebat. Makalah pada Seminar Tentang Kurikulum, Mei 2013 di UNES Semarang.

Pitalokasari, I. 2012. Meninjau Ulang Kurikulum PT. Suara Merdeka, 29 September 2012.

Sanusi, A. 1998a. PendidikanAlternatif: Menyentuh Asas Dasar Persoalan Pendidikan dan Kemasyarakatan, Bandung: PT Grafindo Media Pratama.

Suyadi. 2013. Kurikulum Baru, Berubah Tanpa Galau. Jawa Pos, 11 Januari 2013. 